\title{
Nicole Starbuck
}

University of Adelaide

\section{The Baudin Expedition and the Aborigines of 'Botany Bay' Colonial Ethnography in the Era of Bonaparte}

Recording their entry through Sydney Heads in mid-1802, the members of the Nicolas Baudin Expedition made no mention of the Aboriginal men, women and children who must have been watching from ashore or who, according to custom, most likely rowed out in canoes to meet their ships. Neither did those aboard the Naturaliste, which arrived ahead of the Géographe, express any curiosity about whether their companions, stranded ashore after their dinghy capsized in a storm, had come into contact with the Indigenous people. ${ }^{1}$ Their attention was elsewhere: they counted the other vessels sighted ahead in the port, searched for other discovery ships, and, on the quarter-deck, noted the distant sound of a nine-canon salute - the British colonists, they presumed, were celebrating St George's Day (Breton: 4 floreal an $X$ [24 April 1802]). As they sailed toward the colony, the Frenchmen apparently gave little thought to the Indigenous life around them. They were preoccupied, instead, with anticipation of the comforts and company to be found ahead among their fellow Europeans in Sydney-Town.

To what extent did this attitude continue through the following 5-month sojourn? The expedition's pictorial record suggests, as Margaret Sankey points out (2001: 124), that Baudin's artists enjoyed close contact with the Aborigines of Port Jackson and came to view them with a considerable degree of empathy. However, the written records are noted for their paucity of information and brevity. The official ethnography, published by the expedition's "observer of Man", François Péron, is, as Jean Fornasiero et al. (2004: 380), Jean-Luc Chappey (2014: 144-149) and Bronwen Douglas (2014: 136) illustrate, distant, derogatory, and indicative of emergent racialism. On the whole, existing scholarship asserts that, yes; the voyagers demonstrated a certain lack of interest in the Aborigines of Port Jackson. Historians write of a relative ethnographic silence during these months and of views that these Aborigines were no longer in a 'pristine' 'state of nature' and that they were already ' $k$ nown' by the British (Morphy: 148-163; Fornasiero and West-Sooby: 59-80). I have argued myself that the voyager-naturalists were both disappointed and perplexed, as they perceived these people as being in a liminal state - neither civilised nor savage (Starbuck 2013a: 81-99 and 2013b: 123-133).

Much of this scholarship treats the Port-Jackson ethnographies like those produced from beach encounters; yet, as a result of their colonial context, they might well be considered as constituting a different genre. The colonial context distinctively influenced how the voyagers gathered their knowledge and what meanings they gave to it. ${ }^{2}$ To begin with, it was an existing contact zone, already active with

1 While, at the time, none of the staff expressed curiosity about their colleagues' experience ashore, sub-lieutenant Francois Hérisson later recorded that "some savages and an English fisherman shared five or six fish" with the men. See Journal de Hérisson, entry 7 to 8 floreal [27-28 avril 1802].

2 On the significance of 'space' in the practice of natural history, see Outram, 'New Spaces in Natural History'. 
cross-cultural relationships, understandings and tensions. Joseph-Marie Degérando had wished the voyagers to offer Indigenous people "the pact of a fraternal alliance!", to "take their hand and raise them to a happier state" and, more precisely, to "bring them our arts, and not our corruption, the code of our morality, and not the example of our vices, our sciences, and not our scepticism, the advantages of civilization, and not its abuses" (Degérando: 132). However, the Aborigines of Port Jackson had already been introduced to the 'abuses' of 'civilization' and the corruption and vices of 'civilized' people. Of course, they also were not alone in their contact with the French observers. This was a multifaceted encounter, which involved contact of the Aboriginal inhabitants of Port Jackson and the Baudin Expedition but also of the Indigenous people with other visitors to the port; for example, American merchants and whalers - men of a post-revolutionary nation built on slavery and dispossession; Pacific Islanders, recruited to European whaling and sealing vessels; and the Flinders Expedition, which was planned by Joseph Banks to anticipate French discoveries on the Australian coastline. Most importantly, it also included the settlers, convicts and colonial authorities of Port Jackson (Sankey 2001: 5-36; Nugent 2005: 94-95; Starbuck 2013a: 81-99 and 2013b: 123-133). The Baudin Expedition was surrounded by men and women with their own opinions, anecdotes and commentaries - and some of these served as comparisons to Aboriginal humanity. It is important to keep in mind too that the Aborigines of this region were already 'known' to Europeans - existent on paper and canvas but also on the ground, as colonists bodily and verbally mediated the Frenchmen's ethnographic observations and impressions. Furthermore, the colonial setting, in its physical, social and cultural organisation, altered the focus of their ethnographic lens. As Shino Konishi demonstrates, the European space powerfully evoked Western European standards in the observers' minds (Konishi 2004: 98-115). The context of the colonial town, in particular, had no doubt a crucial influence as well. Naturalists and authorities investigating human diversity in France itself, during the Revolution, treated town populations as neutral, homogeneous; it was to the countryside they looked for data about physical and moral characteristics (Ozouf 1984: 29). For these reasons, it is proposed here that if the Baudin Expedition's Port-Jackson ethnographies are to be understood correctly they must considered specifically as colonial observations of Man.

They need also to be unpacked. It is well established that ethnographic representations vary significantly depending on where, when and for what purpose they were written. Bronwen Douglas, in particular, clearly demonstrates the importance of taking these differences into account (Douglas 2003: 3-27). Yet existing scholarship on this particular body of work has tended to combine rather than distinguish the various types of ethnographic sources which resulted from the Port Jackson sojourn. Compounding this issue is the tendency also to focus on certain records, particularly the ethnographic report Péron published in the Voyage de découvertes. Its sense of intercultural distance and disappointment of not understanding the other is characteristic of its genre and has characterised the history of this encounter.

Accordingly, this article interrogates the expedition's records with attention both to the colonial background of this ethnography and to its structural elements. It is particularly focused on clarifying the characteristics of the encounter itself and in distinguishing the nature of the men's views in the context of their official reports. To this end, it considers the relationships between experience in the field of ethnogra- 
phy, initial observation and publication while, where possible, comparing the men's attitude at Port Jackson to that demonstrated during the other colonial encounters, at Tenerife, Mauritius and Timor. Naturally, an underlying consideration is also the ideological, 'scientific' and political background of the expedition itself.

\section{The Baudin Expedition and the Observation of Man}

The Baudin Expedition, launched in 1800, was representative of the transformation of natural history which had been accelerated by Revolutionary reforms (Bourguet: 802-823; Outram: 249-265; Blanckaert: 117-160; Chappey 2002: 225-380; Jones 2002: 164-175; Harrison 2009: 33-52; Harrison 2012: 39-59; Starbuck 2012: 3-35). Having decided that France no longer needed grand round-the-world voyages of discovery, the Institut National designed for Baudin's command a 'direct expedition' to the still largely unexplored south, west, north and Tasmanian coastlines of Australia (Starbuck 2013a: 2). It also appointed to the Géographe and its consort the Naturaliste an unprecedented 24 men who were specialized in a variety of disciplines - including naturalists, artists and gardeners. This number included one, medical student François Péron, who after presenting to the Institut a paper entitled "Observations sur l'anthropologie", established himself as the expedition's "observer of man". Péron's aim was to test the hypothesis that 'civilization' was detrimental to human health and his work would mark the turn toward the physical anthropology of the nineteenth century. In fact, Baudin's Expedition was the first to carry a self-appointed expert in anthropology, i.e. an 'observer of Man', or anthropological instructions. At the request of the short-lived Société des Observateurs de l'Homme, Baudin was provided with a lengthy treatise composed by Joseph-Marie Degérando which comprehensively detailed questions about 'savage' society and culture and emphasised the concept of a common humanity. He was also given directions from comparative-anatomist Georges Cuvier, intended to guide the collection of anatomical specimens and data that might advance understandings of human diversity (Degerando: 129-169; Cuvier: 171-176).

Indeed, in the preparations for the Baudin Expedition there is clear evidence of what Claude Blanckaert (117-160) describes as a sense of urgency felt by French naturalists to reach a more profound understanding of human nature. Over the course of only a few years, "liberty, equality and fraternity" had been declared, slavery in the colonies had been abolished and the new Republic, embracing all the citizens of France, had been proclaimed une et indivisible. French naturalists had looked both within the departments of France itself and beyond for similarity, as Carol Harrison explains (2012: 40), for they had become deeply invested in the concepts of equality and 'civilisation'; indeed, Marie-Noëlle Bourguet argues that French identity had become entangled in the concept of l'égalité (1976: 812). However, resistance and violent counter-revolutionary action, particularly in the Vendée, had unsettled many citizens' faith in universalism. What William Max Nelson calls the "colonisation of France" was proving a far more challenging task than authorities had anticipated (Nelson: 73-85). By the late 1790s, as Martin Staum demonstrates, scientific and political authorities sought to "stabilise the Revolution", and that involved investigating 
how well its democratic principles were in actual fact suited to the "laws of nature" (Staum 1996).

Chappey explains that, following the return of the expedition to France in 1804, contemporary politics, colonialism and science certainly influenced the published representation of Port Jackson's Aborigines. In the political climate of Napoleon's imperial regime, he writes, universalism and the concept of "noble savagery" were firmly rejected in favour of a view of humanity that was progressively essentialist, taxonomic and biological and which served to justify colonialism and the reintroduction of slavery (Chappey 2014: 139-159). What merits more attention is the extent to which attitudes which predominated prior to the expedition's commencement attitudes centred on the concepts of universalism and social regeneration - coloured representations produced in, or at least near, the colonial contact zone.

\section{The Colonial Contact Zone: Port Jackson 1802}

According to the expedition's records combined with scholarship on the colonial history of New South Wales, the Revolutionary voyagers experienced an extensive and varied encounter with the Aboriginal people of Port Jackson. Their most recent and comparable experience had occurred at the port of Kupang, in Timor. Their first port-of-call had been at Tenerife where, Ronsard points out, "for 200 years there had existed no native inhabitants", and the voyagers had instead observed bodily remains found preserved in caves (Ronsard: 12). They subsequently called in at Mauritius, which had been uninhabited prior to French colonisation but had long been occupied by a large number of African slaves. As the administrators there had refused to acknowledge the National Convention's abolition of slavery in the French empire, these Africans were still enslaved when the Baudin Expedition visited in 1801; unfortunately, the voyagers did not record any reflections on their situation. It was not until their three-month sojourn at Timor, late that year, that Baudin and his men came into daily contact with local Indigenous people. They encountered a diverse society with a 200-year history of European commerce and colonisation. At the British outpost Port Jackson, only 14 years had passed since the arrival of the First Fleet; thus, the Baudin Expedition met the first generation of Aboriginal Australians to experience the establishment of European 'civilisation'.

For the duration of their stay in the British colony, Baudin and the naturalists lodged in Sydney, while the naval officers came ashore regularly to carry out chores and enjoy days at leisure. Consequently, as Baudin noted in a letter to Antoine-Laurent de Jussieu, professor of botany at the Muséum nationale d'histoire naturelle, he and his men saw local Aborigines on a regular basis. Although the Indigenous inhabitants of Port Jackson had generally "retreated into the interior as the English penetrated inland", Baudin and his men encountered Aborigines "often, in town, in the villages and on the main roads" (Baudin to Jussieu: 11 Nov. 1802). Pierre Bernard Milius, first-lieutenant aboard the Naturaliste, received such frequent visits from the infamous Bennelong that he eventually became 'annoyed' by them. Bennelong had been befriended as a young man by Governor Arthur Phillip and subsequently spent several years in London. His English language skills and familiarity with European ways were therefore particularly strong. Individuals like Bennelong - as well as Bungaree, 
who had accompanied Matthew Flinders on the Norfolk in 1799 and travelled with him again on his Australian voyage - no doubt interacted more closely with the members of the Baudin Expedition than other local Aborigines and mediated their inquiries about local Aboriginal society. They, themselves, bridged the European and Indigenous societies, as illustrated by geographer Charles-Pierre Boullanger's observation of Bennelong putting on British clothes to enter Sydney-Town and removing them as he returned to his Indigenous community (Rivière: 580). However, an extensive series of fine-grained portraits, each entitled by its subject's name, suggests that at least the artist Nicolas-Martin Petit developed a high degree of familiarity with a number of local men, women and children. One may assume that at least some of his colleagues, who no doubt observed the portrait sittings, came to know these people as well. Petit's fellow artist with the expedition, Charles-Alexandre Lesueur, produced his own sketches depicting Aboriginal people occupying the same spaces as the Frenchmen. In two 'views' of Sydney, he portrayed Aborigines in canoes alongside the French ships and French sailors in their boats, as well as fishing and lighting a fire on Bennelong Point where the expedition's tents were established and French sailors completed their daily chores. And together with colleagues, the artists also found opportunities to produce notations of Aboriginal music and to obtain a sample of an Aborigine's own drawings. Unfortunately, the Frenchmen provide no explanation of the circumstances or negotiations which allowed these valuable contributions to the expedition's anthropological collection, nor even of where the encounters took place: in town, village or bush. However, Lesueur sketched several 'typical' ethnographic landscapes (Smith: 147-148), which may have been based on personal observations made beyond those parts of the region settled by colonists, while Péron mentions sighting smoke from the campfires of the "miserable hordes who inhabit" the "sad shores" of Botany Bay (Péron 1807: 287). A number of the expedition members ventured well beyond the township of Sydney, as far as the Blue Mountains, and would almost certainly have encountered Aboriginal people in various settings and circumstances along the way. In all, over the course of a winter and subsequent spring in Port Jackson, the voyagers had ample opportunity not only to undertake observations of Aboriginal inhabitants but furthermore to gain considerable familiarity with them and their position in the colony as well as to develop feelings, in some balance, of empathy and aversion.

In fact, this sojourn made possible more than ephemeral encounters. A draft report - prepared by Péron for presentation to the professors of the Institut National - indicates that the naturalist had formed an ongoing, individual, relationship during these months: a collaboration with a young man named Ourou-Mare, called Bull-dog by the settlers. In an unpublished paper, François Péron mentions that he "kept" Ourou-Mare with him throughout the sojourn, for his skill, it would seem, at catching lizards and snakes. It is almost certain that Péron had arranged for Ourou-Mare to catch those reptiles for the expedition's zoological collection, following the example set by George Caley, natural history collector for Joseph Banks and Péron's acquaintance during the sojourn. Caley himself relied on the knowledge and skills of an Aboriginal companion (Karskens: 260).

A significant part of the Baudin Expedition's experience at Port Jackson, reflected in a few lines, was the original inhabitants' adaption, accommodation and resistance to colonisation. By the early nineteenth century, Aboriginal collectors indeed 
played a crucial role in the colony's vigorous natural history economy, not only in the capacity of personal companion but as guides and collectors for any colonial or visiting naturalist. George Caley declared that Aboriginal guides prevented collectors "getting lost and bewildered", they were able to point out the tracks left by animals, and they were "excellent marksmen and quicker-sighted than our people" (Karskens: 260). Moreover, colonists relied on them to obtain the specimens they wished to donate to or use in barter with naturalists. For example, in a letter to Baudin, with whom he was engaged in trade, settler Andrew Thompson wrote: "the cockatoo is lost but I am endeavouring to get another and some young swans from the Natives which if I procure in due time shall be forwarded to you" (Thompson 1802). Nicolas Baudin himself recorded no acknowledgement of collaboration on the part of Aborigines with settlers and naturalists, of their agency as guides and collectors. He did recognise their adaptation in another area when he reported to Antoine de Jussieu that "the natives" had made much further progress in learning the English language than the colonists had in learning theirs (Baudin to Jussieu 1802). Many of the voyagers' own English-language skills were fairly weak - one of Flinders' men commented that he and his French counterparts had had to draw on their Latin in order most effectively to converse; nonetheless, it was undoubtedly more effective for them to use English in their communications with Port Jackson's Aborigines than their own languages. In any case, it was the Aborigines' resistance to the colonial project, rather than their adjustments to it, that seems most strongly to have influenced the Frenchmen's view of the contact zone. As shown further on, the observations recorded in this field are mainly of traditional aspects of local Aboriginal life rather than of Aborigines in the "middle ground" (White 2010), i.e. in the context of intercultural encounter. These native inhabitants had developed strategies for dealing with the incursion on their territories but were by no means embracing European 'civilisation'.

It is worth noting that the Baudin Expedition not only encountered and observed people enduring a process of colonisation but, more precisely, it met them and the colonists during a particular moment in that historical process. In 1802, British settlement and dominance over the Indigenous population remained particularly insecure. While a lack of supplies obliged Governor Philip Gidley King to introduce strict rations throughout the colony, and hostility between King and the officers of the New South Wales Corps intensified, the war between the colonists and Aboriginal resistance forces was reaching a climax. These tensions within the colonial project formed a mosaic lens through which the French must have seen Port Jackson's Aborigines. Only a few weeks before the Géographe's arrival in late June, 1802, the leader of the Indigenous campaign to drive out the colonists was hunted down, killed and beheaded at the Governor's orders (King 1802). The Frenchmen must have known the man responsible: Henry Hacking joined the Flinders Expedition during its stopover at Port Jackson (Karskens: 480). Following Pemulwuy's death, a "second coming in" had occurred but continuing tensions were palpable throughout the colony (Karskens: 480). Only twelve months earlier, Governor Philip Gidley King had ordered all Aborigines to be driven back with gunfire from colonial residences. He had next outlawed Pemulwuy himself and not only offered a reward to colonists but also a promise to the local Aborigines that the war would end if they gave him up (Atkinson: 165-166; Karskens: 478-480). His guests could not have 
missed the hostility between tribes; between Black and White, and amongst the colonists as well - those who resisted King's orders, such as the colony's naturalist George Caley, and those keen to support it, such as the protestant reverend, Samuel Marsden (Karskens: 479). In early June, around a fortnight after the departure of the Naturaliste, and before the expected arrival of the Géographe, Governor King had Pemulwuy's head sent to London (King 1802). Such a specimen would have greatly interested the voyager-naturalists - did they see it before they returned to sea, or did King delay its dispatch till they had gone? The only glimpse in the expedition's papers of hostility between colonists and Aborigines is a note by Jacques F. Emmanuel Hamelin, captain of the Naturaliste, that he had tripled the number of guards on watch at the ship's observatory, located several miles away from Sydney, towards the Heads, "because of thieves who are not rare here and for whom murder is a sport" (Hamelin: 14-15 floréal an X [4-5 May 1802]). Given that he had just arrived in the port, Hamelin would seem to have been echoing advice or anecdotes from his English hosts, and while he may in fact have been referring to convicts, the statement does more closely correspond with colonial-Indigenous relations and, in particular, colonial attitudes toward Aboriginal inhabitants.

In any case, Hamelin did not go on to report any thefts or attacks on the observatory at Green Point. Neither did any of his fellow voyagers report experiences of hostile behaviour from local Aborigines, in general, during the five months of the sojourn. By all accounts, the prolonged and rich encounter was without incident. It was peaceful, in this sense, but also complex. The French Revolutionary voyagers met Aborigines collaborating and trading with settlers and naturalists, acquiring the colonial language, maintaining their culture and everyday practices despite the encroachment of British society across their country. Many Aborigines had risen up against this invasion. On the whole, the Indigenous society they encountered was one on the fringe, between colonial administration and self-governing ethnic groups.

\section{Observations of Man in the Colonial Space}

The observations that Baudin's men made within the contact zone generally did not focus on the Aborigines' native life or circumstances which resulted from the encounter with them. Their records consist merely of remarks that are not only fragmentary but also incidental. In contrast to their reports of beach encounters, the voyagers left no record of their interactions within this zone - of what was said, what gestures were made, who approached who, how, when or where. Perhaps because they involved weeks or, in this case, months of daily sightings and meetings, "the encounter" itself lost its novelty during sojourns in port. Moreover, offering prolonged periods of respite from the life of the ship, these sojourns provided an opportunity to step back from the immediacy of encounter to produce more considered and summative observations. These stays also represented respite from most usual tasks and, consequently, many of the voyagers wrote considerably less or nothing at all during their months at anchor in Port Jackson; indeed, just as they had done at Tenerife, Mauritius and Timor. It would seem safe to assume then that the observations the men actually did choose to record were significant. 
On the ground at Port Jackson, according to the documents available, Nicolas Baudin's men wrote about Aboriginal ways often without, or with only minimal reference to the colonial setting (Rivière: 580; Lesueur: undated). Elsewhere, I have posited that this exclusion was deliberate and, moreover, that the men took this approach because they struggled to reconcile the Aborigines' situation and status in the colony with their own investment in the concept of civilization. However, as implied earlier, care must be taken not to project the attitude inherent in Péron's publication back onto the field observations; perhaps these men simply recorded the aspects of Aboriginal life at Port Jackson that interested them most or, more simply still, that they had been best able to observe. Charles-Alexandre Lesueur and geographer Charles Boullanger both described fishing methods, while Boullanger also wrote about hunting and fighting techniques as well as burial, marriage and childbirth practices. Although only reproduced extracts are currently available (Rivière: 580-581), Boullanger's report, in particular, delves into topics not addressed anywhere else in the expedition's body of ethnographic work and provides a unique degree of depth as well. It provides no indication as to how this information was obtained - it may well have resulted from a combination of direct observation, exchanges of knowledge with Aborigines and colonists, and perhaps also reading of existing accounts - but it was written in a direct rather than manufactured style. All the same, both Boullanger's and Lesueur's reports, in their close attention to detail, indicate the authors' genuine interest in these practices while their reasonably objective style suggests that they had also observed, and possibly gathered advice on, Aboriginal life with a degree of empathy.

The same may be said of Nicolas-Martin Petit's drawings from Port Jackson. Not only the final engravings of his portraits, which were published in the Atlas Historique of the Voyage de découvertes, but, equally, the initial sketches reveal Petit's observation of his subjects' essential humanity. They grant the men and women a nobility and familiarity to European eyes that was not given to Aborigines illustrated in earlier portraits in Tasmania (Fornasiero and West-Sooby 2002: 78). ${ }^{3}$ Whereas the Tasmanians, depicted most often with exaggerated features, stereotypical proportions and classical physiques, are almost caricatures, Petit sketched the people of Port Jackson with sensitive lines and shades that produced natural, lifelike, forms as well as individual personalities revealed in carefully-etched, vivid, expressions. This approach was in fact in line with what Cuvier had instructed Baudin's artists to do: in order to advance his own research on human diversity and, more specifically, on the relationship between "the perfection of the mind and the beauty of the face". The comparative-anatomist requested accurate studies that would represent "the true character of the [subjects'] physiognomy" (Cuvier 1978). Moreover, so well does Petit seem to have followed Georges Cuvier's advice that there are sufficient similarities, in facial features and expressions, across his Port-Jackson portraits, arguably, to represent a racial 'type'. If so, however, this type does not correspond neatly with the textual picture of "weak" bodies, "feeble" constitutions and "fierce" characters that Péron would present in the Voyage de découvertes (Péron 1824: 452). Rather, these portraits have generally in common a certain sadness or pensiveness

3 The portraits appear in Péron [and Freycinet], 1824 and are reproduced in Bonnemains et al., 1988: 137180. For further discussion of Petit's portraits of Port Jackson Aborigines, see Jones, 1988: 58; Sankey, 2004 : 123-124; Fornasiero and West-Sooby, 2002: 77-78 and Fornasiero et al., 2004: 367. Lesueur's drawings are held in the Collection Lesueur at the Muséum d'histoire naturelle, Le Havre. 
expressed in downcast eyes and distant gazes combined with strength and pride in determined frowns and strong jaw lines. The deep scarification and bold ceremonial paints, which - though Cuvier wished excluded - Petit seems to have been at pains to replicate, point to a strong and enduring cultural identity. Ultimately, while they may have represented a 'race', these portraits depicted men and women above all, each of whom Petit had studied closely, attempted to understand, and seemingly appreciated on their individual merits. ${ }^{4}$

While demonstrating a similar focus on universal humanity, Baudin himself forthrightly explained his thoughts on the Aborigines' position in the colony in a personal letter to Governor King. Written during a stopover at King Island, the outburst was prompted in part by a sense of ire that King had sent a party to prevent him from establishing French possession on Tasmania; yet that is not to suggest that it did not reflect the commander's genuine point of view. Baudin likened Aborigines to the peasants of Britain and France and questioned the wisdom of colonising this society while British - and, for that matter, French - society itself was in need of 'civilisation'. "I have never been able to conceive", he revealed,

that there was any justice or even loyalty on the part of Europeans in seizing [...] a land [...] inhabited by men who did not always deserve the titles of 'savages' and 'cannibals' that have been lavished on them, whereas, they were still only nature's children and no more uncivilised than your Scottish Highlanders of today or our peasants of Lower Brittany, etc., who, if they do not eat their fellow men, are no less harmful to them for all that. It would be infinitely more glorious for your nation as for my own to train for society the inhabitants of the countries over which they each have rights, rather than undertaking to educate those who live far away by first seizing the land that belongs to them and to which they belong by birth. (Baudin to King 1802: 826)

Baudin went on to argue that "the distance" the Aboriginal inhabitants keep from the colonists and their customs had been caused "by the idea they formed of the men who wished to live with them". They had discerned the colonists' "future projects", wrote Baudin, but "being too weak to resist" the newcomers, and afraid of their weapons, they had left their land. "The hope of seeing them mix among you is lost", Baudin wrote to King, "and you will soon be left the peaceful possessors of their birthright, as the small number of them living around you will not last long" (Baudin to King 1802: 826). These thoughts correspond to the comment he had made to Antoine-Laurent de Jussieu; in that letter, however, Nicolas Baudin implicitly relates the Aborigines' retreat inland to the view only that they were "useless and little to fear". In that moment, as he had done in Timor as well and as voyager-observers frequently did in general, Baudin drew on the longstanding stereotype of Indigenous indolence (Cornell 2000: 332; Konishi 2012: 127-142). However, from his more reflective letter to King, it is evident that Baudin had carried to Australian shores concerns about the Revolutionary attempt to regenerate French society - concerns which fed a degree of empathy for the distant 'other' and an ambivalence about European colonialism.

Altogether, these field observations represent diverse angles and degrees of insight. Yet while none embraces the Aborigines as equals of Europeans, Petit's and Baudin's, in particular, imply attempts to look for similarity, and all have in common 
a considerable degree of objectivity. They also carry a sense of the observers' familiarity with their subjects, in correspondence with both the nature of the encounter and the Aborigines' position in this contact zone. And, overall, though Baudin's comments are reflective and made in relation to the civilising imperative more than to ethnographic study, these overall are observations of Aboriginal bodies, personalities, practices and fundamental humanity, made effectively in the moment, rather than theoretical evaluations of social progress.

\section{Colonial Ethnography for Publication}

The subsequent ethnographies, written at a distance from the memory of encounter and with a view to publication or other official presentation, contrast distinctly with those which had been composed in the field, i.e. on the ground of research. Rather than describing everyday life or cultural practices, providing careful studies of temperament, morality or intelligence, or reviewing colonial relations of power and influence, these reports reflect a preoccupation with civilization. The view that Port Jackson's Aborigines had seemingly failed to embrace civilization clearly underlies each report and is directly stated time and again. For example, botanist Jean-Baptiste L.C. Théodore Leschenault de la Tour remarked: "although, for several years, the natives of the environs of Sydney have been visiting the English ceaselessly and without fear, they are nonetheless hardly less barbaric than before the arrival of Europeans" (Leschenault 1824 [2007]: 108); First-lieutenant Pierre Bernard Milius wrote: "civilization has made no progress among these people in the 15 years the English have inhabited this island" (Milius 1987: 48), and François Péron declared: "they still live amidst war and alarm" (Péron undated). The incongruent perception of civilising progress - or rather the lack thereof - cast Port Jackson's Aborigines in a negative light: in order to explain these peoples' lack of 'improvement', and simultaneously to uphold European colonialism, Leschenault de la Tour, Milius and Péron looked to shortcomings in the people themselves.

By distinctly divergent reasoning, Milius and Leschenault de la Tour both concluded that Port Jackson's Aboriginal people would never advance to a more 'civilized' state. Milius composed his ethnography during the ten years or so following his return to France, by then the heart of the Napoleonic Empire. It was part of his own narrative of the voyage which he clearly intended to publish. Embedded in the chapter that recounts the expedition's sojourn at Port Jackson, Milius' report sets the state of the local Aborigines in stark contrast to the "view of luxury and civilisation" which the British colony otherwise represented. Milius wrote - with reference particularly to male Aborigines - of a lack of "desire" and a "natural penchant" for "indolence" (Bonnemains and Haugel 1987: 48). This claim he attempts to substantiate with specific examples taken from the colonial context. Firstly, revealing the influence of colonists' mediation, he refers to an anecdote Governor King had told about individuals who ran away from domestic service to resume their "indolent" ways - which supposedly involved depending on the forced labour of Aboriginal women. (Ibid.: 48) Both he and King were drawing upon the common notion of Indigenous men's laziness, ignorance and brutality. Secondly, Milius wrote specifically of Bennelong's "repugnance" for European ways. According to the lieutenant, 
it was ultimately that negative approach which showed it was "impossible to expect to bring the savages of these lands to any idea of civilization". They were, he concluded, "truly stupid brutes who must be left to live their own way" (Ibid. : 49).

For his own part, Leschenault de la Tour posited a theory centred on his belief in the natural environment's predominant influence over human development. His theory was quite briefly stated at the end of a report he wrote on the botany of 'New Holland'. When or where he composed the piece is unclear: as a result of ill health the young botanist had disembarked in Timor, during the final leg of the expedition's voyage, and finally returned to France 1807 following visits to Java and Philadelphia. The report was not published until 1824, when it was added by Louis de Freycinet, following the death of Péron, to the second edition of the Voyage de découvertes. By this point in France, the Bourbon monarchy had been restored and French authorities were looking with envy at British colonial possessions in the Pacific (Dunmore 1969: 386). It was no doubt partly in accordance with this climate that, whereas he had taken a focused ethnographic approach to colonial "natives" in his on-board journal - writing at length on the inhabitants of Timor, if scantly on those of Port Jackson - here Leschenault de la Tour concentrated instead on presenting a people who neither benefitted the British colonial project nor posed an obstacle to Australian colonisation (Undated: 58-88, 185, 187). On the Aborigines of colonial Port Jackson, Leschenault (1824: 107) suggested that "the pressing need to defend their existence" had "destroyed [...] whatever happy moral and intellectual qualities" with which one might credit these "natives". Moreover, he continued: "nature appears to have endowed" these people "with just the sum of intelligence in harmony with the land they inhabit". In fact, in Leschenault's point of view, the problem of the Aborigines' natural environment was insurmountable. There was scant hope, he wrote, that the Aborigines' natural "sum of intelligence" would develop any further for "never, at any time that we had occasion to communicate with them", he declared, "did we notice that degree of curiosity that indicates aptitude and desire for learning".

Similarly, Péron also claimed that the "lack of food, its poor quality, and the labour needed to obtain it" had rendered these "deprived children of Nature" weak and left them to "vegetate" in the savage state (1824: 366-367). However, by contrast to Leschenault and Milius, Péron argued that the condition of these "miserable people" was not fixed. Demonstrating faith in a gradual and organic process of human civilization, Péron imagined the Aborigines eventually forming villages, farming kangaroos, growing stronger, smarter and more morally refined (1824: 367-369). Péron's approach in the voyage ethnography was to rank the peoples he encountered during the expedition according to his calculations of their physical strength and his assessment of their level of social development (1824: 301, 302, 311, 313 and 351-385). The Indigenous people of 'New Holland', who actually comprised those specifically of Port Jackson, were ranked above those of Tasmania but below the peoples of Timor, France and Britain (1824: 359-360). According to François Péron, the differences between these groups had been caused by the advantages or disadvantages of their respective environments - a finding which supported his theory that, contrary to the belief made popular by Jean-Jacques Rousseau, humans do not degenerate but improve with the progress of civilization. Péron even extolled the virtues of the transportation system: He applauded the improved morality and fertility of the convicts and attributed these improvements to the fresh air, varied diet, as well as to 
the orderly social organization established by the colonial authorities (1824: 299-300, 303-305). However, his evaluation of the Aboriginal inhabitants was not purely 'scientific'. In the course of putting forward the results of his research, Péron made frequent use of subjective terms and referred far more frequently to existing colonial histories than to examples of his own, direct, observations. He referenced David Collins' Account of the English Colony in New South Wales [Vol. 1: 1798; Vol.2: 1802] particularly often to support claims about "repulsive" practices, "barbaric actions" and "flaws in conformation" amongst the Aborigines inhabiting the environs of Port Jackson (1824: 364-366, 368-369). In an early draft that he had planned to present to "Messieurs le Professors" (Péron undated), ${ }^{5}$ which he did not in the end find opportunity to present and which he crossed out in heavy lines of ink, Péron did refer to Ourou-Mare and even gave him some praise; however, the memory of a prolonged and what must have been reasonably intimate relationship did not distract him from his argument. "In a word", he wrote, "there is no doubt that exercise and custom has given some advantages to this uncouth and savage man, but alas, one does not envy them: by how much misery, have they acquired them!"

These published ethnographies bore little relation overall to the voyagers' contact experience at Port Jackson; that is, their contact with the Aborigines themselves, as opposed to the British authorities and settlers who claimed to know them. As is typical of edited, published, accounts, these are far more derogatory, distant and general than the observations that were produced within, or at least with fresh memory of, the intercultural contact zone. As colonial ethnographies, more specifically, they are also far more preoccupied with 'civilising' progress and, notably, they are selective to that end: they admit only begrudgingly the Aborigines' English-language skills and give no direct acknowledgement at all of their role in the colonial natural history trade. As Jean-Luc Chappey argues in relation to work of François Péron, they represent personal ambitions and corresponding conformity to contemporary politics above all; indeed, colonial ethnographies, more than their reports about encounters on the beach, lent themselves particularly well to the task of currying favour with an imperialist regime.

\section{Conclusion}

From experience to ethnography, this colonial encounter has a more balanced and complex history of contact and ethnography than previously acknowledged. The nature of the expedition's colonial contact was varied, in relation to the elements of Aboriginal life the voyagers witnessed as well as the types of contact they established, from prolonged individual relationships to regular sightings of everyday life. The observers' views were blurred during these months, not only by an inevitably intense reminder of European values and concerns, produced by the colonial built environment and culture, as well as by the intermediation of colonists with their anecdotes, 'knowledge' and warnings. It was also unsettled by the Aborigines' changing role in an intercultural contact zone.

5 Péron's use of the past tense and a very similar tone to that which characterises the ethnographic chapter of the Voyage suggest that this document was written following the expedition's return to France. 
It is a pity that the members of the Baudin Expedition did not write more directly about the nature of their encounter and at greater length about their observations; however, the paucity of their records is a typical aspect of colonial ethnography. Moreover, what they did leave behind on their contact and observations in this colonial field of research does provide fertile ground for still further study. The fragmentary notes and sketches tell a not-unrelated but significantly different story from that implied in the final reports - that is, reports which are not only more racialist than the earlier, more immediate, observations, as was typical for voyage ethnographies, but which placed the humanity of Australia's Aboriginal people within a colonial frame.

\section{Bibliography}

Atkinson, A., 1997. The Europeans in Australia: A History, Vol. I. Oxford: Oxford University Press.

Baglione, G., and C. Blanckaert, 2008. L'Autre. Catalogue de l'exposition. Muséum d'histoire naturelle du Havre, 21 mars - 15 juin 2008. Le Havre: Éditions du Muséum du Havre.

Baglione, G., and C. Cémière, 2009. Charles-Alexandre Lesueur: Peintre voyageur, un trésor oublié. Paris: Conti.

Baudin, N. to P. G. King, 1802. Elephant Bay, King Island, 3 nivose an XI [24 December 1802], in: F. M. Bladen, ed., 1896, Historical Records of New South Wales, Vol. 5. Sydney: Government Printer, 826.

Baudin, N. to A.-L. de Jussieu, 1802. Port Jackson, 20 brumaire an X [11 November 1802], Muséum national d'histoire naturelle [hereafter MNHN], ms2082, pièce no. 5.

Blanckaert, C., 2000. "1800 - Le moment 'naturaliste' des sciences de l'homme", Revue d'Histoire des Sciences Humaines, 3, 117-160.

Bonnemains, J. and P. Haugel, eds., 1987. Récit du voyage aux Terres australes par Pierre-Bernard Milius, second sur le Naturaliste dans l'expédition Baudin (1800-1804). Le Havre: Société havraise d'études diverses.

Bonnemains, J., E. Forsyth, and B. Smith, eds., 1988. Baudin in Australian Waters: The Artwork of the French Voyage of Discovery to the Southern Lands 1800-1804. Le Havre: Muséum d'histoire Naturelle, Le Havre 1988.

Bourguet, M.-N., 1976. "Race et Folklore: L'Image Officielle de la France en 1800”, Annales. Histoire, Sciences Sociales, 31, 4 (Jul-Aug), 802-823.

Chappey, J.-L.,2002. La Société des Observateurs de l'Homme: Des anthropologues au temps de Bonaparte. Paris: Société des Etudes Robspierristes.

Chappey, J.-L., 2014. "François Péron et la question de la civilisation aux antipodes", Annales historiques de la Révolution française, 1, 139-159.

Chittleborough, A., G. Dooley, B. Glover, and R. Hosking, eds., 2002. Alas for the Pelicans! Flinders, Baudin, and Beyond. Kent Town, S.A.: Wakefield Press.

Cook, A., N. Curthoys, and S. Konishi, eds., 2013. Representing Humanity in the Age of Enlightenment. London: Pickering and Chatto.

Copans, J., and J. Jamins, eds., 1978. Aux Origines de l'Anthropologie: Les Mémoires de la Société des Observateurs de l'Homme en l'an VIII. Paris: Le Sycomore.

Cornell, C., ed., 2000. Mon Voyage aux Terres australes: Journal Personnel du commandant Baudin. Paris: Imprimérie Nationale.

Cuvier, G., 1978. “Note Instructive Sur les Recherches à faire relativement aux différences anatomiques des diverses races d'hommes, 1800", in: J. Copans, and J. Jamins, eds., Aux Origines de l'Anthropologie, 171-176.

Degérando, J.-M., 1978 [1800]. “Considérations sur les diverses méthodes à suivre dans l'observation des peuples sauvages, 1800", in: J. Copans, and J. Jamins, eds., Aux Origines de l'Anthropologie, 129-169.

Desan, S., L. Hunt, and W.M. Nelson, eds., 2013. The French Revolution in Global Perspective. Ithaca: Cornell University Press. 
Douglas, B., 2003. "Seaborne Ethnography and the Natural History of Man", The Journal of Pacific History, 38, 1 (June), 3-27.

Douglas, B., 2014. Science, Voyages and Encounters in Oceania, 1511-1850. Basingstoke: Palgrave.

Dunmore, J., 1969. The French in the Pacific, Vol. II: The Nineteenth Century. Oxford: Oxford University Press.

"Extrait du journal de Théodore Leschenault". ANF série marine 5JJ56.

Fornasiero, J., and J. West-Sooby, 2002. "Taming the Unknown: The Representation of Terra Australis by the Baudin Expedition 1801-1803", in: A. Chittleborough, G. Dooley, B. Glover, and R. Hosking, eds., Alas for the Pelicans! Flinders, Baudin, and Beyond, 59-80.

Fornasiero, J., P. Monteath, and J. West-Sooby, 2004. Encountering Terra Australis: The Australian Voyages of Nicolas Baudin and Matthew Flinders, 1800-1804. Kent Town, S.A.: Wakefield Press.

Harrison, C. E., 2009. "Projections of the Revolutionary Nation: French Expeditions in the Pacific, 1791-1803", Osiris, 24, 33-52.

Harrison, C. E., 2012. "Replotting the Ethnographic Romance: Revolutionary Frenchmen in the Pacific, 1769-1804", Journal of the History of Sexuality, 21, 1 (January), 39-59.

Jardine, N., J.A. Secord, and E.C. Spary, eds., 1996. Cultures of Natural History. Cambridge: Cambridge University Press.

Jones, R., 1988. "Images of Natural Man", in: J. Bonnemains, E. Forsyth and B. Smith, eds., Baudin in Australian Waters: The Artwork of the French Voyage of Discovery to the Southern Lands 1800-1804, 35-64.

Jones, P., 2002. "In the Mirror of Contact: Art of the French Encounters", in: Thomas, S., ed., The Encounter 1802: Art of the Flinders and Baudin Voyages, 164-175.

Journal de François Désiré Breton, ANF série marine 5JJ57, transcribed by M. Jangoux and reproduced in The Baudin Legacy Project, http://sydney.edu.au/arts/research/baudin/ pdfs/breton.pdf, accessed 27 April 2015.

Journal de Jacques Félix Emmanuel Hamelin des Essarts, Capitaine de Frégate Commandant le Naturaliste, Corvette destinée avec celle du Géographe sous les ordres du Capitaine Nicolas Baudin pour une expédition de découvertes, armée at équipée pour 4 ans, t. II. ANF, série marine 5JJ42.

Journal de François Antoine Boniface Hérisson, ANF, série marine 5JJ56, transcribed by M. Jangoux and J. Roubino and reproduced in The Baudin Legacy Project, http://sydney. edu.au/arts/research/baudin/pdfs/heirisson.pdf [accessed 27 April 2015].

Journal de François-Michel Ronsard, ANF série marine 5JJ28: 12, transcribed by D. Bréelle and reproduced in The Baudin Legacy Project, http://sydney.edu.au/arts/research/baudin/ pdfs/ronsardjournal5ji28.pdf, accessed 3 May 2015.

Karskens, G., 2010. The Colony: A History of Early Sydney. Crows Nest, NSW: Allen and Unwin.

King, P. G. to J. Banks, 1802. Sydney, 5 June, in: F. M. Bladen, ed., Historical Records of New South Wales, Vol. IV. Sydney: Government Print, 1896, 782-786.

Konishi, S., 2004. “Depicting Sexuality: A Case Study of the Baudin Expedition's Aboriginal Ethnography", Australian Journal of French Studies, XLI, 2, 98-115.

Konishi, S., 2012. The Aboriginal Male in the Enlightenment World. London: Pickering and Chatto.

Leschenault, T. 2007 [1824]. "Account of the Vegetation of New Holland and Van Diemen's Land", in: F. Péron [L. Freycinet] Voyage of Discovery to the Southern Lands, Vol. III, Dissertations on Various Subjects, trans. C. Cornell. Adelaide: The Friends of the State Library of South Australia.

Lesueur, C.-A., undated. "Pêche des aborigènes du Port Jackson", transcribed J. Bonnemain, CL, MHN Le Havre, dossier 09031.

Morphy, H., 2002. "Encountering Aborigines", in: S. Thomas, ed., The Encounter 1802: Art of the Flinders and Baudin Voyages, 148-163.

Nelson, W. M., 2013. “Colonizing France: Revolutionary Regeneration and the First French Empire", in: S. Desan, L. Hunt, and W.M. Nelson, eds., The French Revolution in Global Perspective, 73-85.

Nugent, M., 2005. Botany Bay: Where Histories Meet. Crows Nest, NSW: Allen and Unwin.

Outram, D., 1996. "New Spaces in Natural History", in: N. Jardine, J.A. Secord, and E.C. Spary, eds., Cultures of Natural History, 249-265.

Ozouf, M., 1984. L'École de la France: Essais sur la Révolution l'Utopie et l'Enseignement. Paris: Gallimard. 
Péron, F., 1800. “Observations sur l'anthropologie ou l'histoire naturelle de l'homme”, in: J. Copans, and J. Jamins, eds., Aux Origines de l'Anthropologie, 177-185.

Péron, F., 1807. Voyage de découvertes aux Terres australes, Vol. II, Historique. Paris: Imprimerie Imperiale.

Péron, F. [and Freycinet, L.], 1824. Voyage de découvertes aux Terres australes: exécuté par ordre de sa Majesté L'Empereur et Roi, sur les corvettes le Géographe, le Naturaliste; et la goëlette le Casuarina, pendant les années 1800, 1801, 1802, et 1804, Historique, 2 ème edition. Paris: Arthus Bertrand.

Péron, F. [and Freycinet, L.], 1824. Voyage de découvertes aux Terres australes: exécuté par ordre de sa Majesté L'Empereur et Roi, sur les corvettes le Géographe, le Naturaliste; et la goëlette le Casuarina, pendant les années 1800, 1801, 1802, et 1804, Historique, Atlas par MM. Lesueur et Petit, $2^{2 \mathrm{eme}}$ edition. Paris: Arthus Bertrand.

Péron, F., undated. "Conférence adressée à 'Messieurs les Professeurs' décrivant les aborigènes et leurs mœurs près de Port Jackson", Collection Lesueur, Muséum d'histoire Naturelle, Le Havre [hereafter CL MHN], dossier $n^{\circ} 09$ 032, transcription J. Bonnemains.

Rivière, P.-L., 1953. “Un Périple en Nouvelle Hollande au début du XIXème siècle”, Compte rendus mensuels de l'Academie des Sciences coloniale, 13, 571-589.

Sankey, M., 2001. “The Baudin Expedition in Port Jackson, 1802: Cultural Encounters and Enlightenment Politics", Explorations, 31 (December), 5-36.

Smith, B., 1960. European Vision and the South Pacific, 1768-1850. Oxford: Oxford University Press.

Starbuck, N., 2012. "The Colonial Field: Science, Sydney and the Baudin Expedition (1802)", Explorations, 52 (June), 3-35.

Starbuck, N., 2013a. Baudin, Napoleon and the Exploration of Australia. London: Pickering and Chatto.

Starbuck, N., 2013b. "Neither Civilised nor Savage: The Aborigines of Port Jackson Through French Eyes, 1802", in: A. Cook, N. Curthoys, and S. Konishi, eds., Representing Humanity in the Age of Enlightenment, 123-133.

Staum, M., 1996. Minerva's Message: Stabilizing the French Revolution. Montreal: McGillQueen's University Press.

Thomas, S., ed., 2002. The Encounter 1802: Art of the Flinders and Baudin Voyages. Adelaide: Art Gallery of South Australia.

Thompson, A. to N. Baudin, Parramatta, 3 November 1802, ANF, SM, 5JJ53.

White, R., 2010. The Middle Ground: Indians, Empires and Republics in the Great Lakes Region, 1650-1815. Cambridge: Cambridge University Press. 